\title{
新しい煎茶用品種 ‘つゆひかり’
}

\author{
静岡県茶業試験場* \\ 小柳津 勤・倉貫 幸一**・中村順行***・ \\ 日高 保****・青島洋一 \\ (平成15年 5 月 22 日受理)
}

\section{A New Cultivar 'Tsuyuhikari’ for Green Tea}

\author{
Tsutomu Oyaizu, Yukikazu Kuranuki, Yoriyuki Nakamura, \\ Tamotsu Hidaka and Yoichi Aoshima \\ Shizuoka Tea Experiment Station
}

\begin{abstract}
Summary
A new tea cultivar named 'Tsuyuhikari' for green tea was developed from seedlings derived from the cross of 'Shizu7132' $\times$ 'Asatsuyu' at the Shizuoka Tea Experiment Station in 1970. The clone was selected by individual selection in 1979. It was evaluated for local adaptability and for a specific characteristics from 1991 to 1997. It was named 'Tsuyuhikari' and adopted as a recommended cultivar of Shizuoka prefecture in 2001.

'Tsuyuhikari' is slightly early budding cultivar. The shape of the plant is medium type and the growth habit is fairly vigorous. The flush shoots show bud weight type and flush leaves are elliptic in shape and light green in color. The cutting of 'Tsuyuhikari' is inferior to 'Yabukita' in rooting, but show good growth after rooting. 'Tsuyuhikari' is more resistant to cold damage in winter than that of 'Yabukita'. It is fairly resistant to tea anthracnose(Colletotrichum theae-sinensis(Miyake)Yamamoto). The yield of green leaves is higher than that of 'Yabukita'. 'Tsuyuhikari' has high quality in the processed tea. It has a little deposits in liquor, but the color of liquor is bright green. The aroma is refreshing, and the taste is mild. 'Tsuyuhikari' adapts itself to any tea cultivated region in Shizuoka prefecture.
\end{abstract}

Key words: Tsuyuhikari, new cultivar, green tea, high-yielding ability, disease resistance

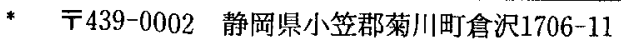

** 現静岡県農業試験場

*** 現静岡県農業水産部抢茶室

$* * * *$ 現静岡県経済農業協同組合連合会
} 


\section{1 緒言}

我が国の茶園面積は, 2001年の統計で 50 ,100haであり，主産県である静岡県 は 20,800haで全国の $41.5 \%$ 占めている*1。普 及品種は‘やぶきた’が極めて多く，全国では 茶園面積の $77 \%$ を占め, 静岡県では $91 \%$ に及 んでいる*2。静岡県の ‘やぶきた’占有率は， 他の主要茶産都府県と比較しても際立って高 い状況にある。‘やぶきた’は，広域適応性や 優良な品質等優れた特性を持ち, 在来種から の転換過程では高い評価を受けて広く普及し てきた。しかし，生産構造や食生活様式の変 化ともあいまって， ‘やぶきた’の寡占状態 は,摘採期集中による製茶工場への過剩投資, 適期摘採を逃すことによる品質低下，気象災 害や病害虫発生等の危険性増大，品質の画一 化で多様な消費赀好に対応できないなど， 様々な問題を引き起こしている。

このような問題に対好するため，‘やぶき た’と組合せ栽培可能な早生, 晚生品種, 減農 薬可能な耐病虫性品種, 多様な消費者の嗜好 に対応できる品種等が求められている。静岡 県では，以上のような情勢を踏まえ，これま でに良質な早生品種 ‘扔いわせ’ ${ }^{11}$ ，山間地 向きの晚生品種 ‘おくひかり’ ${ }^{2}$, 良質多収の 晚生品種 ‘さわみずか’ 3), 耐寒性のある早生 品種 “山の息吹” " , 香味に特徵ある中生品種 “香駿”る㕕成してきた。今回，多収で炭疽病
に強く品質優良な ‘つゆひり’を育成した ので，その育成経過及び試験成績の概要を報 告する。

\section{2 来歴及び育成経過}

‘つゆひかり’は，静岡県茶業試験場におい て1970年に“静7132’を種子親，“あさつゆ’を 花粉親として交配し, 得られた実生群から選 抜，育成された(図 1 )。育成経過は表 1 に示 すとおり，1970年に交配、1971年に採種，播 種し, 個体養成を経て1978 1979年に個体選 抜, 1981年に苗床選抜で選抜した。1982〜1987 年に系統70-30-302として栄養系比較試験を 実施した。生育，品質が優れていた同系統を 1991～1997年に奨励品種决定本試験に供試 し, 静岡県茶業試験場本場（菊川町倉沢）で 生産力及び特性検定試験, 同富士分場（富士 市石坂）及び中川根町農林業センター（中川 根町地名）において地域適応性試験, 本川根 町須山及び森町大河内において特性検定試験 を実施した。その結果, 炭疽病に強く多収で, 前茶用として品質優良と認められたので, 2000年に‘つゆひかり’と命名した。同年, 種 苗法に基づく品種登録を出願し，2003年 3 月 に品種登録された。また，2001年 2 月の静岡 県奨励品種決定審査会に諮り，2001年 4 月に 静岡県茶奨励品種として採用された。なお， ‘つゆひか’の育成担当者は, 表 1 のとおり である。

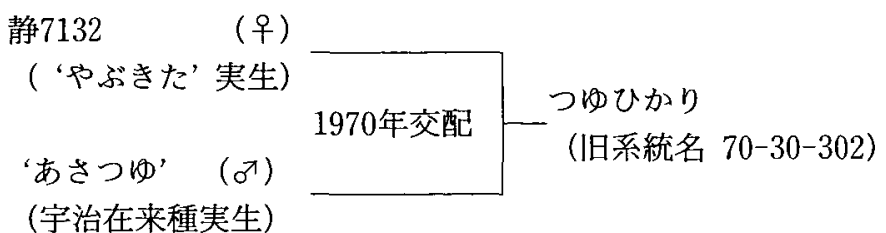

図1‘つゆひかり’の青成系統図

*1 関東農政局静岡統計情報事務所

$* 2$ 社団法人日本茶業中央会：平成 14 年度茶関係資料, p.25(2002). 
(茶研報95：1～15，2003）

表 1 ‘つゆUかり’の育成経過と担当者

\begin{tabular}{|c|c|c|}
\hline 事業内容 & 年 度 & 育成担当者 \\
\hline 交配 & 1970 & 日高 保, 鈴木幸 隆 \\
\hline 採種・播種 & 1971 & 日高 保, 鈴木幸 隆 \\
\hline \multirow[t]{4}{*}{ 個体養成及び選抜 } & $1972 \sim 1975$ & 日高＼cjkstart保 \\
\hline & 1976 & 日高＼cjkstart保, 倉貫幸一 \\
\hline & 1977 & 日高＼cjkstart保, 倉 貫幸一 \\
\hline & $1978 \sim 1979$ & 倉貫幸一, 伊藤 英史 \\
\hline 苗床選抜 & $1980 \sim 1981$ & 倉貫幸一, 中村順行 \\
\hline \multirow[t]{3}{*}{ 栄養系比較試験 } & $1982 \sim 1984$ & 倉貫幸一, 中村順行 \\
\hline & $1985 \sim 1986$ & 中村順行, 松 浦 健 雄 \\
\hline & 1987 & 中村順 行, 小枷津＼cjkstart勤 \\
\hline \multirow[t]{4}{*}{ 奨励品種決定本試験 本場 } & $1991 \sim 1992$ & 倉 貫 幸 一, 青野(柴田)真里子 \\
\hline & 1993 & 倉貫幸一, 永谷隆行 \\
\hline & $1994 \sim 1995$ & 中村順行, 永谷隆行, 青島洋一 \\
\hline & $1996 \sim 1997$ & 中村順行, 青島洋一, 畑中義生 \\
\hline \multirow[t]{3}{*}{ 富土分場 } & 1991 & 小泊重洋 \\
\hline & $1992 \sim 1994$ & 高橋宇正 \\
\hline & $1995 \sim 1997$ & 増沢武雄 \\
\hline \multirow{4}{*}{$\begin{array}{l}\text { 中川根町農林業センター, } \\
\text { 本川根町須山, 森町大河内 }\end{array}$} & $1991 \sim 1992$ & 後藤昇一, 小林栄人 \\
\hline & $1993 \sim 1994$ & 後藤昇一, 鈴木康孝 \\
\hline & 1995 & 塚本均, 鈴木康 孝 \\
\hline & $1996 \sim 1997$ & 鈴木康孝 \\
\hline 品種登録出嫄頁 & 2000 & 小栁津 勤 \\
\hline
\end{tabular}

\section{3 試 験 成 績}

3. 1 育成地（本場）における成績

（1）生育と形態的特性

‘つゅひかり’の樹姿は中間型である。樹勢 は極めて強く，樹高と株張りが大きく秋整枝 量も多い。枝条の節間長は短い(表 2 )。成葉 は長卵形で，大きさは‘やぶきた’と同程度の やや大であり，葉色は緑色で葉縁の波がやや 少なく，反転度がやや小さい(表 3 )。新葉は 形状が楕円形と長楕円形の中間で葉色は淡緑 であり, 大きさ, 厚さ, 光沢及び葉質は中程 度である(表 4 )。

\section{（2）育苗成續}

‘つゆかり’の挿し木における生育を表 5 に示す。地床挿しにおいては, 生存率は‘や ぶきた’よりも低く，挿し木 1 年目の新梢長
と新葉数, 挿し木 2 年目の樹高, 分枝数及び 生育の均整度は ‘やぶきた’より劣り, ‘くら さわ’と同程度であった。ペーパーポット挿 しにおける挿し木 3 力月後及び 5 力月後の生 育は，新葉数は‘や゙゙きた’よりやや多いが， 新芽長と最長根長はやや短く，根重はやや少 なかった。以上のように，'つゅひかり’の挿 し木後の生育は, 地上部, 地下部とも‘やぶき た’より劣り，発根性がやや恶いため生育に ばらつきが生じ，苗の均整度も‘やぶきた’よ り劣る結果となった。しかし, 活着後の苗の 生育は良好であった（表 6 )。

（3）幼木期の生育

‘つゆひかり'の幼木期の生育を表 6 に示 す。樹高は ‘やぶきた’ と同程度であり，株張 りは‘やぶきた’以上に広くなる。また，定植 3 年目の秋整枝量は ‘くらさわ’よりも多く, 
幼木期の生育は極めて旺盛であった。

\section{（4）萌芽期及び摘採期}

‘つゆひかり’の萌芽期は，‘やぶきた'に 比べ1日早く，“さやまかおり’と同じであ る。摘採期は‘やぶきた’より 2 日，“さやま かおり’より1日早く，“つゆひかり’はやや 早生と位置づけられる(表 7 )。
（5）赤枯れ及び炭疽病の発生程度

育成地における‘つゆひり’の寒害（赤枯 れ）の発生状況は，‘やぶきた’と同程度であ る(表 8)。'つゆひかり’の炭疽病の発生は, ‘やぶきた’や‘くらさわ’と比べて極めて少な い(表 9)。その他の病害は，ほとんど発生し なかったため，比較評価できなかった。

\section{表 2 生育と形態的特性}

\begin{tabular}{|c|c|c|c|c|c|c|c|c|c|c|}
\hline \multirow{2}{*}{ 品種名 } & \multirow{2}{*}{ 樹 } & \multirow{2}{*}{ 株張り } & \multirow{2}{*}{$\frac{\text { 株張り }}{\text { 枹 高 }} \times 100$} & \multicolumn{2}{|c|}{ 秋整枝量 ${ }^{a}$} & \multirow{2}{*}{ 樹 } & \multirow{2}{*}{ 樹 槷 } & \multicolumn{2}{|c|}{ 枝条の形質 } & \multirow{2}{*}{ 着葉角度 } \\
\hline & & & & $10 \mathrm{a}$ 当り & 摘採面当り & & & 節間長 & 太さ & \\
\hline & $\overrightarrow{\mathrm{cm}}$ & $\mathrm{cm}$ & $\%$ & $\mathrm{~kg}$ & $\mathrm{~g} / \mathrm{m}^{2}$ & & & $\mathrm{~mm}$ & $\mathrm{~mm}$ & 度 \\
\hline つゆひかり & 126 & 182 & 136 & 1615 & 1455 & 中 & 極強 & 32 & 3.3 & 25 \\
\hline やぶきた & 105 & 162 & 128 & 700 & 684 & やや直 & やや強 & 50 & 3.2 & 24 \\
\hline ざやまかおり & 108 & 168 & 134 & 883 & 835 & 中 & 強 & 50 & 3.1 & 18 \\
\hline くらさわ & 108 & 177 & 162 & 809 & 706 & やや開 & 強 & 46 & 3.1 & 26 \\
\hline
\end{tabular}

$\mathrm{a} ：$ 定植 7 年目, 1997年10月調査。

b ：(株張り/樹高) $\times 100$ は，1994～1997年の平均値。

c：調查は一番茶芽の生育停止期の枝条中央部で実施。

\section{表 3 成葉の特性}

\begin{tabular}{|c|c|c|c|c|c|c|c|c|c|c|}
\hline 品種名 & 形 & 先端長 & 大きさ & 厚 d & 色 & 光 沢 & 葉面のしわ & 葉縁の波 & 内折度 & 反転度 \\
\hline つゆひかり & 長 卵 & 極 短 & やp大 & 中 & 緑 & やや多 & 中 & やや少 & 中 & やや小 \\
\hline やぶきた & 長楕円 & 極 短 & pp大 & 中 & 緑 & やゃ多 & 中 & やや多 & 中 & 中 \\
\hline ささやまかおり & 長槡円 & 極 短 & やや大 & 中 & 濃 & 中 & やゃ多 & 多 & 中 & 中 \\
\hline くらさわ & 長棈円 & 短 & 大 & やや薄 & 淡 緑 & 中 & 中 & 中 & 中 & 中 \\
\hline
\end{tabular}

調査は一番茶芽の生育停止期の枝条中央部で実施。

\section{表 4 新葉の特性}

\begin{tabular}{|c|c|c|c|c|c|c|}
\hline 品 種 名 & 状 & 大きさ & 厚 & 色 & 光 沢 & 葉 質 \\
\hline$つ ゆ ひ か り$ & 棈円一長棈円 & 中 & 中 & 淡 緑 & 中 & 中 \\
\hline やぶきた & 長棈円 & 中 & 中 & 緑 & 中 & やや軟 \\
\hline さやまかおり & 長楕円 & 中 & 中 & 濃 緑 & 中 & 中 \\
\hline くらさわ & 長桎円一披針 & 中 & 中 & 濃 緑 & 中 & やや軟 \\
\hline
\end{tabular}


(茶研報95：1～15，2003）

表 5 挿し木における生育

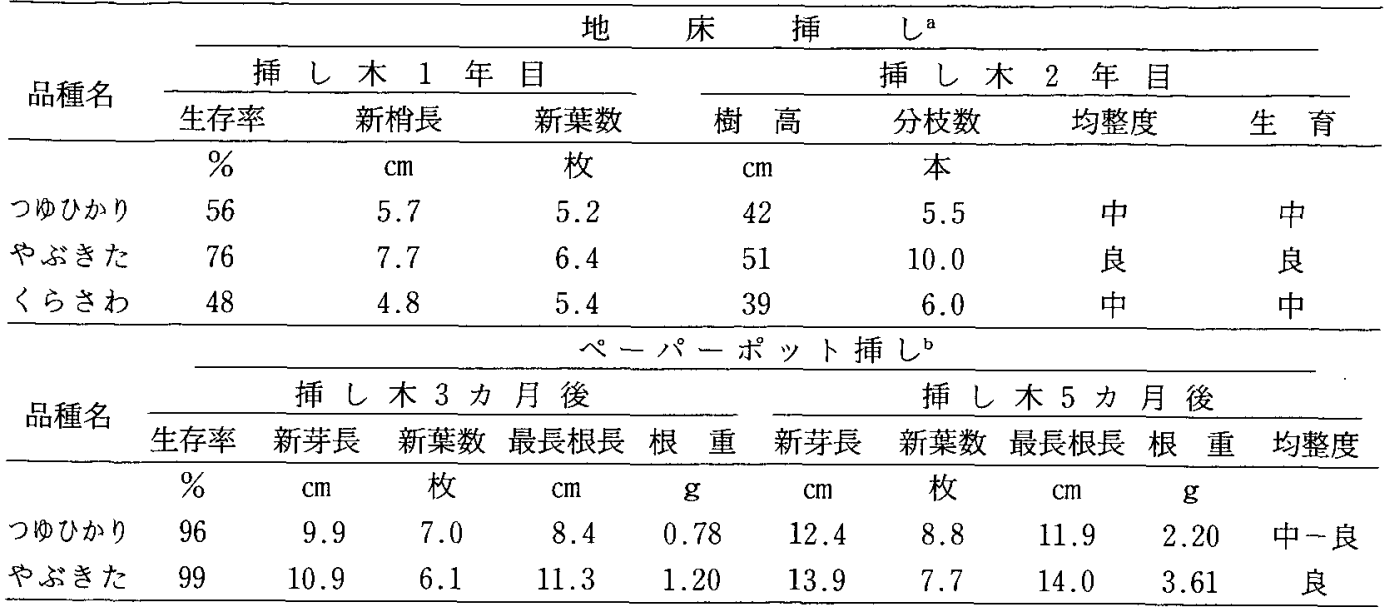

$\mathrm{a}$ ：地床挿しは1980，1981年の苗床選抜成績，1980年 6 月挿し。

$\mathrm{b}$ ：ペーパーポットの大きさは直径 $6 \mathrm{~cm}$ 深さ $15 \mathrm{~cm} ， 2002$ 年 6 月挿し。

\section{表 6 幼木期の生育}

\begin{tabular}{|c|c|c|c|c|c|c|c|c|}
\hline \multirow{2}{*}{ 品種名 } & \multicolumn{3}{|c|}{ 樹高 } & \multicolumn{3}{|c|}{ 株張り } & \multicolumn{2}{|c|}{ 秋整枝量 ( 3 年目) } \\
\hline & 1 年目 & 2 年目 & 3 年目 & 1 年目 & 2 年目 & 3 年目 & $10 \mathrm{a}$ 当り & 摘採面当り \\
\hline & $\mathrm{cm}$ & $\mathrm{cm}$ & $\mathrm{cm}$ & $\mathrm{cm}$ & $\mathrm{cm}$ & $\mathrm{cm}$ & $\mathrm{kg}$ & $\mathrm{g} / \mathrm{m}^{2}$ \\
\hline つゆひかり & 63 & 71 & 98 & 50 & 89 & 145 & 752 & 1130 \\
\hline やぶきた & 60 & 69 & 95 & 35 & 68 & 124 & 408 & 752 \\
\hline さやまかおり & 59 & 59 & 84 & 38 & 68 & 130 & 348 & 647 \\
\hline くらさわ & 51 & 56 & 84 & 45 & 86 & 146 & 463 & 800 \\
\hline
\end{tabular}

定植後 $1 \sim 3$ 年目 (1991 1993年)の10月の生育を示す。

表 7 一番茶の萌芽日及び摘採日

\begin{tabular}{|c|c|c|c|c|c|c|c|c|c|c|}
\hline \multirow{2}{*}{ 品種名 } & \multicolumn{5}{|c|}{ 萌芽日 （月，日） } & \multicolumn{5}{|c|}{ 摘採日 (月. 日) } \\
\hline & 1994年 & 1995年 & 1996年 & 1997年 & 平 均 & 1994年 & 1995年 & 1996年 & 1997年 & 平均 \\
\hline つ的ひかり & 4.3 & 4.4 & 4.8 & 3.30 & 4.4 & 4.29 & 5.3 & 5.6 & 4.29 & 5.2 \\
\hline やぶきた & 4. 7 & 4.6 & 4.5 & 3.31 & 4.5 & 5. 2 & 5.4 & 5.8 & 5. 2 & 5.4 \\
\hline さやまかおり & 4. 6 & 4.6 & 4.5 & 3.31 & 4.4 & 4.30 & 5.4 & 5.8 & 5. 1 & 5.3 \\
\hline くらさわ & 4.10 & 4.3 & 4.1 & 3.28 & 4.3 & 4.29 & 5.3 & 5.6 & 4.30 & 5.2 \\
\hline
\end{tabular}

表 8 赤枯れの発生状況

\begin{tabular}{cccccccc}
\hline 品種名 & 1993 年 & 1994年 & 1995年 & 1996年 & 1997年 & 平 均 \\
\hline つゆひか & 2 & 1 & 3 & 1 & 3 & 2.0 \\
やぶきた & - & 3 & 3 & 2 & 2 & 2.0 \\
さやまかおり & 1 & - & 2 & 1 & 1 & 1.0 \\
くらさわ & - & - & 3 & 2 & 3 & 1.6 \\
\hline
\end{tabular}

発生程度：-(無), 1 (少) 〜 5 (多) のグレード評価スコア。 
新しい前茶用品種 ‘つひかり’

表 9 炭疽病の発生状況

\begin{tabular}{ccccccccc}
\hline 品種名 & 1991 年 & 1992 年 & 1993年 & 1994年 & 1995 年 & 1996年 & 1997年 & 平 均 \\
\hline つゆひかり & - & - & 1 & 1 & 1 & - & - & 0.4 \\
やぶきた & - & - & 3 & - & 1 & 2 & 3 & 1.3 \\
さやまかおり & - & - & 5 & 1 & 3 & 5 & 5 & 2.7 \\
くらさわ & - & - & 3 & 1 & 1 & - & 2 & 1.0 \\
\hline
\end{tabular}

発生程度：-(無)，1 (少) 〜 5 (多) のグレード評価スコア。

（6）収量性

‘つゆひかり’の10a 当たり生葉収量は, 1997年を除きややぶきた’より多かった。定植 3 年目から 7 年目までの ‘やぶきた’に対す る指数平均で一番茶収量が $129 \%$ ，二番茶が $133 \%$ ，年間では $131 \%$ を示した。単位摘採面 当たりの生葉収量も多く, 5 年間の やぶき た’に対する指数平均で,一番茶収量が $116 \%$, 二番茶が $117 \%$, 年間では $117 \%$ ありり， ‘つりかり’の収量は, 多収の“さやまか打 り’ゃ'くらさわ’よりも優れていた（表10, 11)。

一番茶及び二番茶の摘芽特性は, 百芽重及び 芽数とも‘やがきた'と同程度であった (表12)。

\section{（7）荒茶品質}

1994〜1997年の一番茶及び二番茶の官能検 査による品質評点の平均值を表13に示す。 ‘つゆひかり'は, 合計点及び小計点（色沢+ 表10 10 a 当たり生葉収量

\begin{tabular}{|c|c|c|c|c|c|c|c|}
\hline 茶期 & 品種名 & 1993年(3) & 1994年(4) & 1995年(5) & 1996年(6) & 1997年(7) & 指数平均 \\
\hline \multirow{5}{*}{ 一番茶 } & & $\mathrm{kg}$ & $\mathrm{kg}$ & $\mathrm{kg}$ & $\mathrm{kg}$ & $\mathrm{kg}$ & \\
\hline & つめかり & 173 & 310 & 560 & 590 & 623 & 129 \\
\hline & やぶきた & 142 & 261 & 334 & 405 & 675 & 100 \\
\hline & さやまかおり & 94 & 212 & 356 & 507 & 672 & 96 \\
\hline & $く ら さ わ$ & 151 & 292 & 457 & 498 & 761 & 118 \\
\hline \multirow{4}{*}{ 二番茶 } & つゆひかり & 284 & 514 & 566 & 749 & 427 & 133 \\
\hline & やぶきた & 219 & 296 & 418 & 550 & 466 & 100 \\
\hline & さやまかおり & 171 & 380 & 513 & 760 & 629 & 120 \\
\hline & $く ら さ わ$ & 231 & 455 & 499 & 705 & 609 & 127 \\
\hline \multirow{4}{*}{ 年 間 計 } & つゆひかり & 458 & 824 & 1,126 & 1,339 & 1,050 & 131 \\
\hline & やぶきた & 360 & 556 & 752 & 955 & 1,141 & 100 \\
\hline & さやまかおり & 265 & 592 & 869 & 1,268 & 1,301 & 108 \\
\hline & $く ら さ わ$ & 382 & 747 & 956 & 1,203 & 1,370 & 123 \\
\hline
\end{tabular}

年次横の（）内は定植後の年数。指数は‘やぶきた’を100とした。
香気十滋味)では, 一番茶, 二番茶とも‘やぶ きた’と同等で, ‘さやまか抢り〈くらさ’よ りも高かった。特に一番茶の形状, 色沢及び 二番茶の香気の評点が高かった。つつゆひか り’の概評は以下のとおりである。形状は粉 がやや多いが細よれし，色沢は鮮緑である。 水色は沈渣と溜りがやや認められるが明るい 緑色を示す。香気は爽やかであり，滋味は旨 味に富み温和である。特に水色及び香気に特 徵があり, 消費嗜好の多様化に対応できる品 質を具備していると考えられる。

‘つゆひかり’の荒茶の化学成分を表14に 示す。一番茶では‘やぶきた，さやまかおり， くらさわ’に比べ全窒素, 総遊離アミノ酸及 びテアニンが多く, タンニンが少なかった。 二番茶では全窒素, カフェイン, 総遊離アミ ノ酸が‘やぶきた’と同程度で，タンニンが少 なかった。 
（茶研報95：1１5，2003）

表11 単位摘採面当たり生葉収量

\begin{tabular}{|c|c|c|c|c|c|c|c|}
\hline 茶期 & 品種名 & 1993年(3) & 1994年(4) & 1995年(5) & 1996年(6) & 1997年.(7) & 指数平均 \\
\hline \multirow{5}{*}{ 一 番茶 } & & $\mathrm{g} / \mathrm{m}^{2}$ & $\mathrm{~g} / \mathrm{m}^{2}$ & $\mathrm{~g} / \mathrm{m}^{2}$ & $\mathrm{~g} / \mathrm{m}^{2}$ & $\mathrm{~g} / \mathrm{m}^{2}$ & \\
\hline & つゆひかり & 385 & 463 & 613 & 592 & 590 & 116 \\
\hline & やぶきた & 409 & 345 & 432 & 478 & 701 & 100 \\
\hline & さやまかおり & 307 & 346 & 431 & 567 & 660 & 98 \\
\hline & くらさわ & 356 & 375 & 468 & 493 & 698 & 101 \\
\hline \multirow{4}{*}{ 二 番茶 } & つゆひかり & 650 & 733 & 669 & 697 & 412 & 117 \\
\hline & やぶきた & 618 & 484 & 500 & 619 & 489 & 100 \\
\hline & さやまか打り & 536 & 626 & 650 & 784 & 642 & 121 \\
\hline & くらさわ & 556 & 600 & 546 & 660 & 584 & 110 \\
\hline \multirow{4}{*}{ 年間計 } & 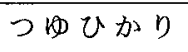 & 1,035 & 1,213 & 1,282 & 1,288 & 1,002 & 117 \\
\hline & やぶきた & 1,027 & 829 & 932 & 1,097 & 1,190 & 100 \\
\hline & さやまかおり & 842 & 973 & 1,081 & 1,351 & 1,302 & 110 \\
\hline & $く ら さ わ$ & 912 & 974 & 1,014 & 1,153 & 1,282 & 106 \\
\hline
\end{tabular}

年次横の（）内は定植後の年数。指数は‘やぶきた’を100とした。

表12 一番茶及び二番茶の摘芽特性

\begin{tabular}{|c|c|c|c|c|c|c|c|c|}
\hline \multirow{2}{*}{ 品種名 } & \multicolumn{4}{|c|}{ 一番茶 } & \multicolumn{4}{|c|}{ 二番茶 } \\
\hline & 摘芽長 & 開葉数 & 百芽重 & 摘芽数 & 摘芽長 & 開葉数 & 百芽重 & 摘芽数 \\
\hline & $\mathrm{cm}$ & 枚 & $g$ & 本 & $\mathrm{cm}$ & 枚 & $g$ & 本 \\
\hline つゆひかり & 7.3 & 4.2 & 56 & 59 & 5.6 & 4.0 & 57 & 59 \\
\hline やぶきた & 7.6 & 3.7 & 54 & 60 & 6.0 & 3.5 & 53 & 58 \\
\hline さやまかおり & 6.0 & 3.2 & 50 & 63 & 6.4 & 3.4 & 71 & 59 \\
\hline くらさわ & 6.5 & 3.6 & 56 & 52 & 6.5 & 3.5 & 61 & 58 \\
\hline
\end{tabular}

調査は $20 \times 20 \mathrm{~cm}$ 枠摘み。1994年（定植 4 年目） 1997年（定植7年目）の 4 年間の平均値を示す。

表13 一, 二番茶の荒茶品質（官能検査）

\begin{tabular}{|c|c|c|c|c|c|c|c|c|}
\hline 茶 期 & 品種名 & 形 状 & 色 沢 & 香 気 & 水 色 & 滋 味 & 小 計 & 合 計 \\
\hline \multirow{4}{*}{ 一番茶 } & つけかり & 16.3 & 17.3 & 16.9 & 15.6 & 16.3 & 50.4 & 82.3 \\
\hline & やぶきた & 15.4 & 16.6 & 17.1 & 17.5 & 17.3 & 51.0 & 83.9 \\
\hline & さやまかおり & 17.3 & 15.6 & 15.5 & 15.5 & 15.4 & 46.5 & 78.9 \\
\hline & くらさわ & 16.9 & 16.1 & 15.5 & 15.4 & 14.0 & 45.6 & 78.3 \\
\hline \multirow{4}{*}{ 二番茶 } & つゆかり & 13.8 & 14.0 & 13.9 & 12.1 & 13.0 & 40.9 & 66.8 \\
\hline & やぶきた & 14.3 & 14.1 & 13.0 & 13.3 & 13.4 & 40.5 & 68.0 \\
\hline & さやまかおり & 13.1 & 11.6 & 11.8 & 12.8 & 12.5 & 35.9 & 61.8 \\
\hline & くらさわ & 12.6 & 13.4 & 12.6 & 11.5 & 11.1 & 37.1 & 61.3 \\
\hline
\end{tabular}

官能検查評点は, 各項目 20 点満点。1994年(定植 4 年目) 1997年 (定植 7 年目)の 4 年間の平均値を示す。 小計は色沢十香気十滋味。製茶は $1994 ， 1995$ 年は $500 \mathrm{~g}$ 型，1996，1997年は $2 \mathrm{~kg}$ 型少量製茶機で行った。 


\section{表14 一, 二番茶の荒茶成分}

\begin{tabular}{|c|c|c|c|c|c|c|c|}
\hline 茶期 & 品種名 & 全窒素 & カフェイン & タンニン & 総遊離アミノ酸 & テアニン & ビタミンC \\
\hline \multirow{5}{*}{ 一番茶 } & & $\%$ & $\%$ & $\%$ & $\%$ & $\%$ & $\%$ \\
\hline & $つ ゆ ひ か り$ & 6.4 & 2.4 & 11.7 & 3.8 & 2.1 & 0.54 \\
\hline & やぶきた & 5.1 & 2.8 & 14.8 & 2.5 & 1.3 & 0.62 \\
\hline & さやまかおり & 5.4 & 3.0 & 15.4 & 3.0 & 1.6 & 0.54 \\
\hline & $<ら さ わ$ & 5.0 & 2.6 & 15.2 & 2.4 & 1.3 & 0.53 \\
\hline \multirow{4}{*}{ 二番茶 } & 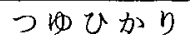 & 3.7 & 1.9 & 12.2 & 0.7 & 0.5 & 0.33 \\
\hline & やぶきた & 3.7 & 1.9 & 15.6 & 0.7 & 0.5 & 0.54 \\
\hline & さやまかおり & 3.9 & 2.3 & 17.8 & 0.5 & 0.4 & 0.51 \\
\hline & くらさわ & 3.4 & 2.3 & 18.0 & 0.1 & 0.1 & 0.49 \\
\hline
\end{tabular}

分析は，近赤外分析法により2001年の荒茶について行った。

3.2 静岡県内に扔ける地域適応性試験

（1）地域適応性試験地における生育

火山灰土地带の富士市に位置する富士分場 及び大井川中流域の山間地域に位置する中川 根町農林業センターに扔ける生育状況を表 15〜17に示す。

‘つけひり’の幼木期の生育は，育成地と 同様に優れて抢り，樹高は‘やぶきた’と同程 度で，株張りは‘やぶきた’より大きく，秋整 枝量は‘くらさわ’よりも多かった。定植 7 年
目の成木期の生育は, 富士分場では樹高が ‘やぶきた’より大きく，‘くらさわ’と同程度 で, 農林業センターでは, 樹高, 株張りとも 'くらさわ'より大きかった。秋整枝量は，い ずれの試験地とも‘さやまかおり，くらさわ” より多く，生育は良好であった。

萌芽期及び摘採期は，富士分場では‘やぶ きた’と同じであり，農林業センターでは‘や ぶきだより 2 日早かった。

\section{表15 地域適応性試験地における幼木期の生云}

\begin{tabular}{|c|c|c|c|c|c|c|c|c|c|c|c|}
\hline \multirow{2}{*}{ 試験地 } & \multirow{2}{*}{ 品種名 } & \multicolumn{3}{|c|}{ 樹高 ${ }^{a}$} & \multicolumn{3}{|c|}{ 株張り } & \multicolumn{3}{|c|}{ (株張り/樹高) $\times 100$} & \multirow{2}{*}{ 整枝量b } \\
\hline & & 1 年目 & 2 年目 & 3 年目 & 1 年目 & 2 年目 & 3 年目 & 1 年目 & 2 年目 & 3 年目 & \\
\hline \multirow{5}{*}{ 富士分場 } & & $\mathrm{cm}$ & $\mathrm{cm}$ & $\mathrm{cm}$ & $\mathrm{cm}$ & $\mathrm{cm}$ & $\mathrm{cm}$ & $\%$ & $\%$ & $\%$ & $\mathrm{~kg} / 10 \mathrm{a}$ \\
\hline & つゆひかり & 55 & 92 & 48 & 52 & 85 & 99 & 96 & 101 & 206 & 245 \\
\hline & やぶきた & 66 & 103 & 44 & 38 & 59 & 75 & 58 & 57 & 167 & 58 \\
\hline & さやまかわり & 61 & 97 & 44 & 48 & 63 & 78 & 78 & 65 & 178 & 116 \\
\hline & くらさわ & 61 & 94 & 45 & 48 & 69 & 78 & 80 & 74 & 175 & 143 \\
\hline \multirow{4}{*}{$\begin{array}{l}\text { 中川根町 } \\
\text { 農 林 業 } \\
\text { センター }\end{array}$} & 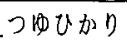 & 47 & 61 & 93 & 39 & 70 & 97 & 84 & 115 & 104 & 702 \\
\hline & やぶきた & 49 & 59 & 87 & 35 & 60 & 85 & 72 & 102 & 98 & 391 \\
\hline & 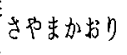 & 43 & 54 & 84 & 31 & 61 & 86 & 72 & 113 & 102 & 454 \\
\hline & くらさわ & 38 & 52 & 78 & 34 & 66 & 94 & 89 & 126 & 120 & 544 \\
\hline
\end{tabular}

a : 樹高, 株張りは，定植後 $1 \sim 3$ 年目（1991 1993年）の10月の生育を示す。

b : 整枝量は, 富士分場は1993年10月の秋整枝量を, 中川根町農林業センターは1993年 3 月の春整枝量を 示す。 
(茶研報95：1～15，2003）

表16 地域適応性試験地における成木期の生育

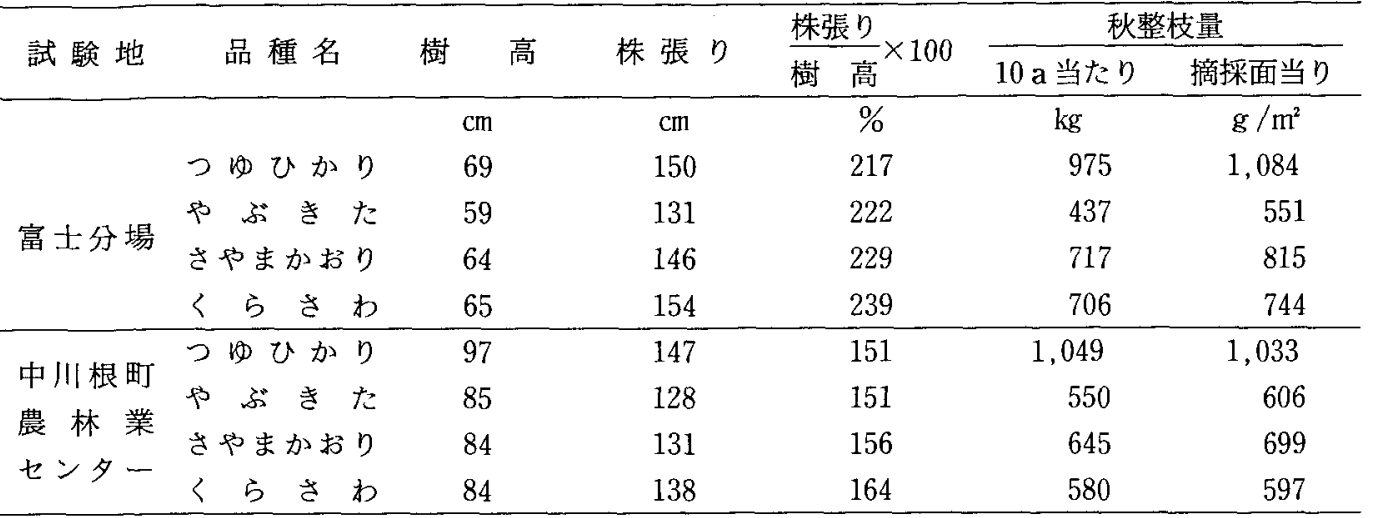

定植 7 年目（1997年）10月の生育を示す。

表17 地域適応性試験地における萌芽日及び一番茶摘採日

\begin{tabular}{|c|c|c|c|c|c|c|c|c|c|c|c|}
\hline \multirow{2}{*}{ 試験地 } & \multirow{2}{*}{ 品種名 } & \multicolumn{5}{|c|}{ 萌芽日 （月．日） } & \multicolumn{5}{|c|}{ 摘採日 (月. 日) } \\
\hline & & 1994年 & 1995年 & 1996年 & 1997年 & 平均 & 1994年 & 1995年 & 1996年 & 1997年 & 平均 \\
\hline \multirow{4}{*}{ 富士分場 } & 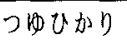 & - & 4.10 & $4: 10$ & 4. 2 & 4.7 & 4.28 & 5.4 & 5.8 & 4.29 & 5. 2 \\
\hline & $た$ & - & 4.11 & 4. 9 & 4. 2 & 4. 7 & 4.28 & 5. 4 & 5.7 & 4.30 & 5. 2 \\
\hline & & - & 4.11 & 4. 8 & 4. 1 & 4. 7 & 4.28 & 5. 4 & 5.7 & 4.29 & 5. 2 \\
\hline & くらさわ & - & 4. 6 & 4. 7 & 3.31 & 4. 4 & 4.27 & 4.27 & 5. 3 & 4.29 & 4.29 \\
\hline \multirow{4}{*}{$\begin{array}{l}\text { 中川根町 } \\
\text { 農 林 業 } \\
\text { センター }\end{array}$} & つ物ひ功 & 4.16 & 4.14 & 4.12 & 4. 4 & 4.12 & 5.9 & 5.3 & 5.13 & 5. 2 & 5.7 \\
\hline & やふ & 4.17 & 4.16 & 4.13 & 4. 8 & 4.14 & 5.10 & 5. 8 & 5.14 & 5. 5 & 5. 9 \\
\hline & & 4.15 & 4.16 & 4.12 & 4. 9 & 4.13 & 5.7 & 5. 8 & 5.12 & 5.6 & 5. 8 \\
\hline & くらさわ & 4.13 & 4.10 & 4. 9 & 4. 4 & 4. 9 & 5. 5 & 5.3 & 5.12 & 5. 2 & 5. 6 \\
\hline
\end{tabular}

\section{表18 地域適応性試験地における赤枯れの発生状況}

\begin{tabular}{|c|c|c|c|c|c|c|c|c|}
\hline 試験地 & 品種名 & 1992年 & 1993年 & 1996年 & 1995年 & 1996年 & 1997年 & 平 均 \\
\hline \multirow{4}{*}{ 富士分場 } & つけかり & - & 1 & $\sim$ & - & - & 3 & 0.7 \\
\hline & やぶきた & - & 1 & 1 & - & - & 2 & 0.7 \\
\hline & さやまかおり & - & 1 & 1 & - & - & 2 & 0.7 \\
\hline & くらさわ & - & 1 & 1 & - & 1 & 3 & 1.0 \\
\hline \multirow{4}{*}{$\begin{array}{l}\text { 中川根町 } \\
\text { 農 林 業 } \\
\text { センター }\end{array}$} & つゆひかり & - & 1 & - & - & - & - & 0.2 \\
\hline & やぶきた & 1 & 2 & 1 & 1 & 1 & 1 & 1.2 \\
\hline & さやまかおり & - & 1 & - & - & 1 & - & 0.3 \\
\hline & くらさわ & 1 & 1 & - & 1 & 1 & 1 & 0.8 \\
\hline
\end{tabular}

発生程度：-(無)，1 (少) 〜 5 (多) のグレード訐価スコア。 
表19 地域適応性試験地における炭疽病の発生状況

\begin{tabular}{|c|c|c|c|c|c|c|c|c|c|}
\hline 試験地 & 品種名 & 1991年 & 1992年 & 1993年 & 1996年 & 1995年 & 1996年 & 1997年 & 平 均 \\
\hline \multirow{4}{*}{ 富士分場 } & つゆひかり & & 1 & 1 & 1 & 1 & 1 & - & 0.8 \\
\hline & やぶきた & & 1 & 1 & 1 & 1 & 2 & 2 & 1.3 \\
\hline & さやまかおり & & 1 & 1 & 1 & 2 & 1 & 3 & 1.5 \\
\hline & くらさわ & & 1 & 1 & 1 & 1 & 1 & 1 & 1.0 \\
\hline \multirow{4}{*}{$\begin{array}{l}\text { 中川根町 } \\
\text { 農 林 業 } \\
\text { センター }\end{array}$} & つゆひかり & - & - & - & - & 2 & - & - & 0.3 \\
\hline & やぶきた & - & 1 & 1 & - & 1 & - & 1 & 0.6 \\
\hline & さやまかおり & 1 & 1 & 1 & - & 1 & - & 2 & 0.9 \\
\hline & くらさわ & - & 1 & 1 & - & 2 & - & 1 & 0.7 \\
\hline
\end{tabular}

発生程度：-(無), 1 (少) 〜 5 (多) のグレード評洒スコア。1991年の富士分場は調查なし。

表20地域適応性試験地における10a当たり生葉収量

\begin{tabular}{|c|c|c|c|c|c|c|c|c|}
\hline 試験地 & 茶期 & 品種名 & 1993年(3) & 1994年(4) & 1995年(5) & 1996年(6) & 1997年(7) & 指数平均 \\
\hline \multirow{13}{*}{ 富士分場 } & \multirow{5}{*}{ 一番茶 } & & $\mathrm{kg}$ & $\mathrm{kg}$ & $\mathrm{kg}$ & $\mathrm{kg}$ & $\mathrm{kg}$ & \\
\hline & & つゆひかり & 232 & - & 409 & 583 & 556 & 156 \\
\hline & & やぶきた & 173 & - & 251 & 371 & 324 & 100 \\
\hline & & さやまかおり & 308 & - & 379 & 472 & 354 & 141 \\
\hline & & くらさわ & 217 & - & 204 & 323 & 465 & 109 \\
\hline & \multirow{4}{*}{ 二番茶 } & つゆひかり & 129 & - & 407 & 643 & 495 & 183 \\
\hline & & やぶきた & 64 & - & 205 & 359 & 327 & 100 \\
\hline & & さやまかおり & 110 & - & 314 & 527 & 430 & 151 \\
\hline & & くらさわ & 112 & - & 319 & 636 & 425 & 159 \\
\hline & \multirow{4}{*}{ 年 間 計 } & つゆひかり & 361 & - & 816 & 1,226 & 1,050 & 165 \\
\hline & & やぶきた & 237 & - & 456 & 730 & 650 & 100 \\
\hline & & さやまかおり & 417 & - & 694 & 999 & 784 & 146 \\
\hline & & くらさわ & 328 & - & 524 & 958 & 889 & 130 \\
\hline \multirow{12}{*}{$\begin{array}{l}\text { 中川根町 } \\
\text { 農 林 業 } \\
\text { センター }\end{array}$} & \multirow{4}{*}{ 一番茶 } & つゆひかり & - & 207 & 207 & 422 & 552 & 106 \\
\hline & & やぶきた & - & 207 & 242 & 333 & 491 & 100 \\
\hline & & さやまかおり & - & 180 & 292 & 351 & 613 & 109 \\
\hline & & くらさわ & - & 172 & 191 & 323 & 460 & 88 \\
\hline & \multirow{4}{*}{ 二番 茶 } & 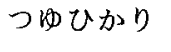 & - & 330 & 376 & 686 & 635 & 146 \\
\hline & & やぶきた & - & 186 & 367 & 373 & 530 & 100 \\
\hline & & さやまか㧍り & - & 189 & 410 & 483 & 671 & 117 \\
\hline & & くらさわ & - & 212 & 324 & 365 & 395 & 94 \\
\hline & \multirow{4}{*}{ 年間 計 } & つゆひかり & - & 537 & 583 & 1,108 & 1,187 & 126 \\
\hline & & やぶきた & - & 393 & 610 & 706 & 1,021 & 100 \\
\hline & & さやまかおり & - & 369 & 702 & 834 & 1,284 & 113 \\
\hline & & くらさわ & - & 384 & 515 & 687 & 855 & 91 \\
\hline
\end{tabular}

年次横の（）内は定植後年数。指数は‘やぶきた’を100とした。

富士分場の1994年は，晚霜害のため著しく収量に影響したため除外した。

中川根町農林業センターの1993年は摘採しなかった。 
（2）地域適応性試験地における寒害及び病害 の発生状況

寒害（赤枯れ）と炭疽病の発生状況を表18, 19に示す。'つゆひかり’における赤枯れの発 生は, 富士分場では ‘やぶきた’ と同程度で あったが, 農林業センターでは‘やぶきた’よ り少なく ‘さやまかおり’と同程度であった。 ‘つゆひかり’に抢ける炭疽病の発生は, い ずれの試験地とも‘やぶきた'より少なく, 富 士分場では ‘くらさわ”程度の発生が見られ たが, 農林業センターでは‘くらさわ’よりも 発生が少なかった。その他の病害は, ほとん ど発生しなかった。

（3）地域適応性試験地における収量

‘つゆひかり’の10a 当たり生葉収量を表 20に示す。‘やぶきた’に対する指数平均は, 富士分場では一番茶収量が $156 \%$, 二番茶が 183\%そして年間では165\%と多かった。農林
業センターでは一番茶収量が106\%, 二番茶が 146\%そして年間では $126 \%$ あった。特に， 試験地では富士分場，茶期では二番茶におい て多収の傾向が顕著であった。

\section{（4）地域適応性試験地におりる荒茶品質} 官能検査による荒茶品質評点は, 表210と おりである。合計点及び小計点(色沢十香気十 滋味) では, ‘つゆひかり’は富士分場, 農林 業センターとも‘やぶきた’ と同レベルであ り，“さやまかおり,くらさわ’よりも高かっ た。官能検查項目別では, 香気の評点が農林 業センターの一番茶を除き高かった。滋味の 評点は‘さやまかおり’よりも高かったもの の‘やぶきた’よりやや低く，水色の評点は低 かった。形状の評点は農林業センターの一番 茶で高かったが, 概して低い評価であった。 色沢は‘やぶきた’と同等であった。

表21地域適応試験地における一，二番茶の荒茶品質（官能検査）

\begin{tabular}{|c|c|c|c|c|c|c|c|c|c|}
\hline 試験地 & 茶 期 & 品種名 & 形 状 & 色 沢 & 香 気 & 水 色 & 滋 味 & 小 計 & 合 計 \\
\hline \multirow{8}{*}{ 富士分場 } & \multirow{4}{*}{ 一番茶 } & つゅひかり & 13.8 & 14.0 & 13.9 & 12.1 & 13.0 & 40.9 & 66.8 \\
\hline & & やぶきた & 14.3 & 14.1 & 13.0 & 13.3 & 13.4 & 40.5 & 68.0 \\
\hline & & さやまかおり & 13.1 & 11.6 & 11.8 & 12.8 & 12.5 & 35.9 & 61.8 \\
\hline & & くらさわ & 12.6 & 13.4 & 12.6 & 11.5 & 11.1 & 37.1 & 61.3 \\
\hline & \multirow{4}{*}{ 二番茶 } & つゆひかり & 13.8 & 14.0 & 13.9 & 12.1 & 13.0 & 40.9 & 66.8 \\
\hline & & やぶきた & 14.3 & 14.1 & 13.0 & 13.3 & 13.4 & 40.5 & 68.0 \\
\hline & & さやま加招り & 13.1 & 11.6 & 11.8 & 12.8 & 12.5 & 35.9 & 61.8 \\
\hline & & くらさわ & 12.6 & 13.4 & 12.6 & 11.5 & 11.1 & 37.1 & 61.3 \\
\hline \multirow{8}{*}{$\begin{array}{l}\text { 中川根町 } \\
\text { 農 林 業 } \\
\text { センター }\end{array}$} & \multirow{4}{*}{ 一番茶 } & つゆひかり & 16.3 & 17.3 & 16.9 & 15.6 & 16.3 & 50.4 & 82.3 \\
\hline & & やぶきた & 15.4 & 16.6 & 17.1 & 17.5 & 17.3 & 51.0 & 83.9 \\
\hline & & さやまかおり & 17.3 & 15.6 & 15.5 & 15.5 & 15.4 & 46.5 & 78.9 \\
\hline & & くらさわ & 16.9 & 16.1 & 15.5 & 15.4 & 14.0 & 45.6 & 78.3 \\
\hline & \multirow{4}{*}{ 二番茶 } & つゆひかり & 13.8 & 14.0 & 13.9 & 12.1 & 13.0 & 40.9 & 66.8 \\
\hline & & やぶきた & 14.3 & 14.1 & 13.0 & 13.3 & 13.4 & 40.5 & 68.0 \\
\hline & & さやまかおり & 13.1 & 11.6 & 11.8 & 12.8 & 12.5 & 35.9 & 61.8 \\
\hline & & くらさわ & 12.6 & 13.4 & 12.6 & 11.5 & 11.1 & 37.1 & 61.3 \\
\hline
\end{tabular}

官能検查評点は, 各項目 20 点満点。1994年(定植 4 年目) 1997年(定植 7 年目)の 4 年間の平均値を示す。 小計は色沢+香気十滋味。 
3 . 3 特性検定試験

（1）特性検定試験地における寒害の発生状況 山間地域に属する本川根町須山及び森町大河 内における寒害 (赤枯れ) の発生状況を表 $22 に$ 示す。'つゆひかり’に扔ける赤枯れの発生は, 森町大河内では‘やぶきた’と同程度であったが, 本川根町須山では‘やぶきた’より少なく“さや まかおり’と同程度であった。

（2）特性検定試験地における病害の発生状況 病害の発生状況を表23に示す。'つゆひかり' における炭疽病の発生は, 本川根町須山及び森 町大河内とも‘やぶきた’より少なく, 本川根町 須山では‘くらさわ’程度の発生が見られたが, 森町大河内では‘くらさわ’よりも発生は少なか力 た。'つゆひかり’のもち病の発生は, ‘くらさ わ’より少なく ‘やぶきた’と同程度であった。

\section{4 ‘つゆひかり’嗜好調查}

2003年 2 月に開催された中遠農業フォーラム （静岡県袋井市）において，試飲による‘つゆ ひかり'の嗜好アンケート調査を実施した。対象 は生産者及び消費者であり，回答者数は34人で， 男性 23 人，女性11人であった。年齢は，20代か ら70代まで幅広かった。調查結果は表24に示す とおりである。'つゆひかり’を「好き」または

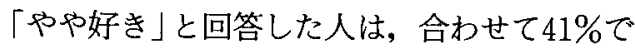
あり，「嫌い」と「やや嫌い」を合わせた $16 \% よ$ りも高かった。滋味については,「味が薄い」が $50 \%$ で最も多く，次いで「旨味がある」が $38 \%$ ， 「甘味がある」が29\%であった。「渋味がある」 と「苦味がある」は，それぞれ $9 \% ， 6 \%$ と少 なかった。香気については，「好き」と「やや好 き」を合わせると $51 \%$ であり,「やや嫌い」が $9 \%$ で「嫌い」の回答は無かった。香りの強さは，

表22 特性検定試験地における赤枯れの発生状況

\begin{tabular}{|c|c|c|c|c|c|c|c|c|}
\hline 試験地 & 品種名 & 1992年 & 1993年 & 1996年 & 1995年 & 1996年 & 1997年 & 平 均 \\
\hline & つゆひかり & 1 & 2 & 1 & - & 2 & 1 & 1.2 \\
\hline 本川根町 & やぶきた & 2 & 3 & 3 & 1 & 2 & 2 & 2.2 \\
\hline 須 & さやまかおり & 1 & 3 & 2 & - & 1 & - & 1.2 \\
\hline & くらさわ & 2 & 3 & 2 & 1 & 2 & 1 & 1.8 \\
\hline & つゅひかり & - & 1 & 1 & 2 & 2 & - & 1.0 \\
\hline 町 & やぶきた & - & 1 & 2 & 1 & 2 & - & 1.0 \\
\hline 大 河 内 & さやまかおり & - & 2 & 1 & - & 1 & - & 0.7 \\
\hline & くらさわ & - & 1 & 3 & 1 & 1 & - & 1.0 \\
\hline
\end{tabular}

発生程度：-(無)，1 (少) 〜 5 (多) のグレード評価スコア。

\section{表23 特性検定試験地における病害の発生状況}

\begin{tabular}{|c|c|c|c|c|c|c|c|c|c|c|c|c|c|}
\hline \multirow{2}{*}{ 試験地 品種名 } & \multicolumn{8}{|c|}{ 炭 疽 病 } & \multicolumn{5}{|c|}{ も 5 病 } \\
\hline & 1991年 & 1992年 & 1993年 & 1996年 & 1995年 & 1996年 & 1997年 & 平均 & 1991年 & 1992年 & 1993年 & 1997年 & 平 均 \\
\hline 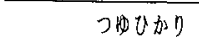 & 1 & 1 & 1 & 1 & 1 & 1 & 1 & 1.0 & 1 & - & 1 & 1 & 0.4 \\
\hline 本川根町やぶきた & 1 & 2 & 3 & 3 & 2 & 5 & 2 & 2.6 & 2 & - & 1 & 1 & 0.6 \\
\hline 山さやま加湤 & 1 & 2 & 4 & 3 & 2 & 5 & - & 2.4 & 2 & - & 1 & 2 & 0.7 \\
\hline くらさわ & - & 1 & 1 & 1 & 2 & 1 & 1 & 1.0 & 4 & 1 & 1 & 3 & 1.3 \\
\hline 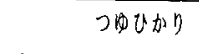 & 1 & 1 & 2 & - & 1 & 2 & 1 & 1.1 & - & 1 & 4 & 1 & 0.9 \\
\hline 森 町やぶきた & 2 & 1 & 4 & 3 & 4 & 4 & 3 & 3.0 & 2 & 1 & 4 & 1 & 1.1 \\
\hline 大河内さ跡加招り & 2 & 5 & 5 & 5 & 5 & 4 & 5 & 4.0 & - & 1 & 3 & 1 & 0.7 \\
\hline くらさわ & 1 & 1 & 2 & 2 & 4 & 3 & 3 & 2.3 & 2 & 1 & 5 & 3 & 1.6 \\
\hline
\end{tabular}

発生程度：-(無)，1 (少) 〜 5 (多) のグレード評価スコア。もち病の1994〜1996年は発生無し。 
表24 ‘つゆひかり’の試飲アンケート

\begin{tabular}{|c|c|c|c|c|c|}
\hline 設問／選択肢 & & 回答率 & 設問／選択肢 & & 回答率 \\
\hline つゆひかり'は好きですか & & $\%$ & 香りは好きですか & & $\%$ \\
\hline 好 & き & 28 & 好 & き & 18 \\
\hline p & き & 13 & やや好 & $き$ & 33 \\
\hline 普还 & 通 & 44 & 普 & 通 & 39 \\
\hline やや嫌 、 & $い$ & 13 & やや嫌 & い & 9 \\
\hline 嫌 $\quad$ V & w & 3 & 嫌 & $w$ & 0 \\
\hline 味はどうでしたか（複数回答 & & $\%$ & 香りの強さはどうですか & & $\%$ \\
\hline 味 が薄 レ & & 50 & 強 & $い$ & 0 \\
\hline 旨味がある & & 38 & や強 & $w$ & 13 \\
\hline 甘味がある & & 29 & 普 & 通 & 66 \\
\hline 渋味がある & & 9 & やや弱 & w & 19 \\
\hline 苦味がある & る & 6 & 弱 & い & 3 \\
\hline 味が濃 レ & w & 6 & & & \\
\hline
\end{tabular}

‘つゆひかり’についての感想

・味がまろやかで若者好み ・さわやかな味・・抹茶の味に似ている・色、味に上品さがある

・さっぱりしている

・さわやかな香り

- 化粧の匂い

・色が鮮やかで好きな色

・色はすばらしい

・匂いも味も少ない

・インパクトがない

・くせが無さ過ぎる

・夏にごくごく飲むにはいい

2003 年 2 月の中遠農業フォーラム（静岡県袋井市）において実施。回答者数 34 人。

「弱い」または「やや弱い」と感じた人が，「強 い」または「やや強い」と感じた人よりやや多 かった。また，水色については「色鮮やかで好 きな色」等の評価するコメントが得られた。以 上の結果から‘ゆひかり’は, 爽やかで,さっ ぱりとしたライトな感じの香味を有し, 日常手 軽に飲用できる茶としての需要が期待できると 考えられた。

\section{5 栽培適地並びに栽培・製造上の留意点}

'つゆひかり'は, 赤枯れ抵抗性及び炭疸病抵 抗性が強く，育成地並びに火山灰土地带や山間 地域のいずれにおいても生育が良好で, 収量, 品質ともに優れた。このことから'つゆひかり’ の地域適応性は広く, 静岡県では茶栽培地帯の 全域に適する。

栽培上の留意点として, 樹勢が強く, 初期生 育が旺盛で管理し易いが, 新芽が芽重型になり やすいので，芽数が増えるような仕立てや，整 剪枝を行う必要がある。また，生葉特性から製 茶加工時に形状を作りにくく, 粉が出やすいこ
とから，製造条件に注意する必要がある。

\section{6 命名の 由 来}

‘つゆひかり’は, 天然玉露といわれる父親‘あ さつゆ’の優れた品質を継承しているとともに, 茶業に光明を与えるという意味を込めて命名さ れた。

\section{7 摘 要}

‘つゆひかり’は, 静岡県茶業試験場において, 1970年に‘静7132’を種子親，“あさつゆ’を花 粉親として交配した実生群から選抜, 育成され た。系統70-30-302として1991年から1997年ま で地域適応性試験及び特性検定試験を実施した 結果, 煎茶用品種として優良であると認められ たため, ‘つゆひかり'と命名し，2001年に静岡 県奨励品種として採用された。'つゆひかり’の 特性の概要は次のとおりである。

萌芽期は‘やぶきた’より 1 日程度早く, 摘採 期は 2 日程度早いやや早生品種である。樹姿は 中間型であり, 初期生育旺盛で, 樹勢が極めて 
強い。新葉は鮮やかな淡緑で, 葉形は長棈円形 と棈円形の中間である。成葉は緑色の長卵形で あり，葉縁の波はやや少ない。挿し木発根性は やや劣るが,活着後の苗の生育は良好である。赤 枯れ抵抗性は‘やぶきた’より強い。而病性は炭 疽病には極めて強く，もち病には‘やぶきた’と 同程度に強い。収量は‘やぶきた’より高く，摘 芽は芽重型である。品質は ‘やぶきた’ と同等に 優れる。外観はやや粉が多いが鮮緑で細よれす る。水色は沈渣がややみられるが，明るい緑色 を示す。香気は爽やかで, 滋味は調和がとれ温和 である。地域適応性に優れ,冷涼な山間地域から 温暖な地域まで広範な地域に適応可能である。

\section{8 謝 辞}

本品種の育成に当たり, 育種試験にご協力い ただいた村松実氏 (現，榛原町切山)，当場技能 長杉沢忠義氏及び品質調查にご協力をいただい た製茶・新製品スタッフ諸氏並びに関係各位に
深甚の謝意を表する。

\section{9 引用 文 献}

1）日高 保・倉貫幸一(1978)：煎茶用新品種 「おおいわせ」．茶研報，№.47,1-10。

2）中村順行-松浦健雄・日高 保・倉買幸一・ 大石貞男・伊藤英史 (1986)：煎䒩用新品種 「おくひかり」.静岡茶試研報, №.12, 23-32.

3 ）倉貫幸一・柴田真里子·中村順行・日高 保 （1994）：煎茶用新晚生品種 ‘さわみずか’. 静岡茶試研報, No.18, 1-11.

4 ）倉貫幸一・青野（柴田）真里子・永谷隆行・ 中村順行・日高 保(1997)：煎茶用の新し い早生品種 ‘山の息吹 (やまのいぶき)'。 静岡茶試研報, No.21, 1-11.

5 ）中村順行・永谷隆行-倉貫幸一日高 保青野 (柴田) 真里子(1999)：香味豊かな煎 茶用新品種 ‘香駿”。静岡茶試研報, №.22, 23-33.

附表 1 ‘つゆひかり’の主要形質における特性

\begin{tabular}{|c|c|c|c|c|c|}
\hline \multicolumn{2}{|c|}{ 形質 } & 特性 & \multicolumn{2}{|c|}{ 形質 } & 特性 \\
\hline 樹姿 & & 中間 & 枝条 & 節間長 & 短 \\
\hline 樹勢 & & 極強 & & 太さ & 中 \\
\hline 株張り & & 大 & & 着葉角度 & 中 \\
\hline \multirow[t]{3}{*}{ 摘採期の茶芽 } & 芽数 & やや多 & 萌芽期 & & pp早 \\
\hline & 摘芽長 & やや長 & 摘採期 & & やや早 \\
\hline & 百芽重 & やや大 & 括し木発根性 & & 中 \\
\hline \multirow[t]{5}{*}{ 新葉 } & 形 & 楕円一長棈円 & 収量性 & 幼木期 & 極多 \\
\hline & 大きさ & 中 & & 成木期 & 多 \\
\hline & 色 & 淡緑 & 製品 & 形状 & 上 \\
\hline & 光沢 & 中 & & 色沢 & 上 \\
\hline & 葉質 & 中 & & 香気 & 上 \\
\hline \multirow[t]{10}{*}{ 成葉 } & 形 & 長卵形 & & 水色 & 上 \\
\hline & 先端長 & 無一短 & & 滋味 & 上 \\
\hline & 大きさ & pや大 & 化学成分 & 全窒素 & やや多 \\
\hline & 厚さ & 中 & & アミノ酸 & やや多 \\
\hline & 色 & 緑 & & カフェイン & 中 \\
\hline & 光沢 & やや多 & & タンニン & 少 \\
\hline & 葉面のしわ & 中 & 耐寒性 & 赤枯抵抗性 & 強 \\
\hline & 葉縁の波 & やや少 & 病害抵抗性 & 炭疽病 & 強 \\
\hline & 内折度 & 中 & & もち病 & やや強 \\
\hline & 反転度 & やや小 & & & \\
\hline
\end{tabular}




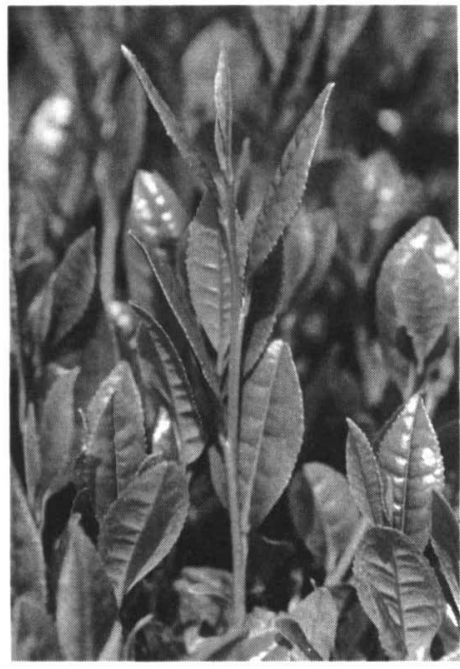

写真 1 ‘つゆひかり’の 一番茶新芽

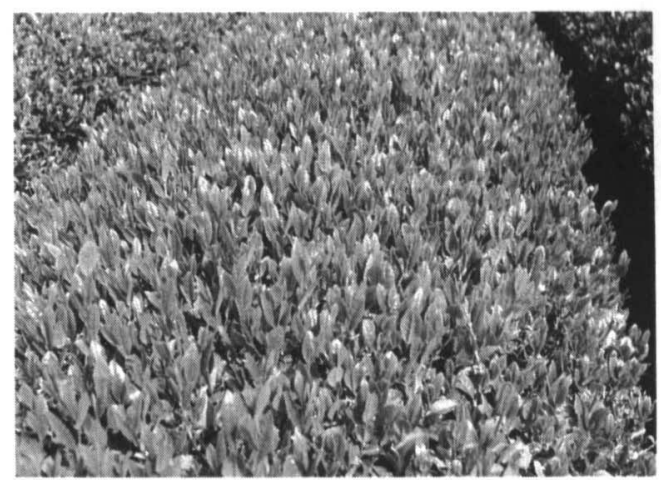

写真 2 ‘つゆひかり’ の一番茶園相

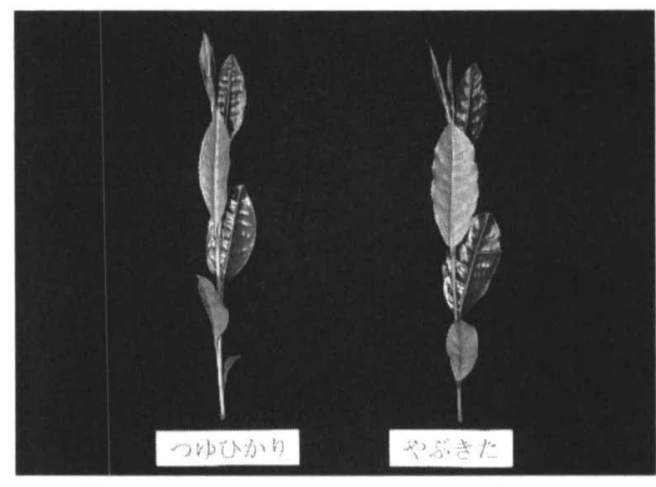

写真 3 ‘つゆひかり’と ‘やぶきた’の 新芽の比較 